\title{
Gazetecilik Bölümü Öğrencilerinin Gözünden Yeni Medya Çağında Gazetecilik'
}

\author{
Günseli Bayraktutan ${ }^{2}$ \\ Nedim Serhat Bilecen ${ }^{3}$ \\ Ali Karakaya ${ }^{4}$ \\ Barıș Yetkin ${ }^{5}$
}

Öz

Bu çalışmanın amacı, gazetecilik alanında lisans eğitimi alan geleceğin habercilerinin yeni medya çağında medya profesyonelliği bağlamında özellikle dijitalleşme ile birlikte ortaya çıkan görünümleri nasıl anlamlandırdıklarını ve gelecekten beklentilerini ortaya koyabilmektir.

Bunun için Giresun Üniversitesi Tirebolu İletişim Fakültesi bünyesinde etkinlik gösteren Gazetecilik Atölyesi'nde katıımcı olan gazetecilik bölümü lisans öğrencileriyle 2018 akademik yılının bahar döneminde odak grup görüşmeleri yapılmıştır. Bu öğrencilerin seçilme nedeni ileriki yaşamlarında profesyonel olarak habercilik alanında çalışmaya niyetlenmiş bireylerden oluşmalarıdır. Söz konusu atölye için niyet mektubu yazarak ve bir mülakat sonucu seçilmişlerdir. Bu nedenle alana ilişkin kavrayışları ve beklentileri bağlamında hem entelektüel düzey hem de pratik anlamda diğer öğrencilerden daha donanımlı oldukları varsayılmaktadır.

Odak grup görüşmeleri aracılığıyla öğrencilerin gazetecilik mesleği bağlamında gelecekten beklentileri, geleceği nasıl çerçeveledikleri, mesleği nasıl anlamlandırdıkları, dijital çağda gazetecilik tartışmalarına egemen kavramları ve süreçleri nasıl değerlendirdikleri (örn. veri gazeteciliği, kitle fonlu gazetecilik, kullanıcı türevli içerik vb.) ve etik tartışmasını yeni medya dolayımlı nasıl kavradıklarına ilişkin düşünce ve yaklaşımları öğrenilmeye çalışılmıştır.

Çalışmanın yan hedeflerinden birisi de geleceğe dönük gazetecilik eğitiminin gözden

1 Bu çalışma, 1-3 Kasım 2018 tarihleri arasında Akdeniz Üniversitesi İletişim Fakültesi tarafından düzenlenen 3. Uluslararası Medya Çalışmaları Sempozyumunda sözlü bildiri olarak sunulmuştur.

2 Doç.Dr. , Giresun Üniversitesi Tirebolu İletişim Fakültesi, Radyo Televizyon Sinema Bölümü, gunseli. bayraktutan@giresun.edu.tr

3 Öğr.Gör. Giresun Üniversitesi Tirebolu İletişim Fakültesi, Gazetecilik Bölümü

4 Arş.Gör. Giresun Üniversitesi Tirebolu İletişim Fakültesi, Gazetecilik Bölümü, ali.karakaya85@gmail.com 5 Dr. Öğr. Üyesi, Giresun Üniversitesi Tirebolu İletişim Fakültesi, Gazetecilik Bölümü, baris.yetkin@giresun. edu.tr 
geçirilmesi sürecine dijital yerli diye tanımlayabileceğimiz bir kuşağın geribildirimlerini de dâhil edebilmektir.

Anahtar Sözcükler: Yeni Medya, Gazetecilik, Dijital Yerliler, Gazetecilik Eğitimi, Gazetecilik Öğrencileri

\title{
Journalism In The Age Of New Media From The Perspective of Journalism Sudents
}

\begin{abstract}
The aim of this study is to be able to present how journalists of the future who are currently undergraduates in journalism see implications of media professionalism, especially those come along with digitalization within the context of new media, and their future expectations about the issue. For this purpose, focus group interviews were held during the spring semester of 2018 academic year with undergraduate students of journalism department participating in the Journalism Atelier organized in Giresun University Tirebolu Faculty of Communication. The main reason why these students were decided on is that they plan to work professionally in field of journalism in their future lives. They were selected on the basis of their letter of intent and interviews for the atelier. For this reason, it is assumed that they are intellectually and practically much more equipped than other students within the context of comprehension and expectation regarding the field.

The focus group discussions are based on the topics like their future expectations on the basis of journalism, how they frame the future, how they perceive the profession, how they perceive concepts and processes that dominate debates on journalism in the digital age (e.g. data journalism, crowd sourcing in journalism, user generated content)- and how they perceive ethics regarding new media. The study also aims to be able to include feedbacks from a generation that we can define as digital natives to the process of reviewing the future of journalism education.
\end{abstract}

Keywords: New Media, Journalism, Digital Natives, Journalism Education, Journalism Students 


\section{Giriș}

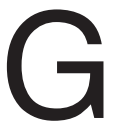

azetecilik alanında teknolojiyle birlikte gerçekleşen dönüşüm mesleğin tüm dinamiklerini etkilemiştir. Özellikle internet teknolojisi ve mobilitenin geleneksel medya ile aynı altyapı ve platformları kullanarak bir araya gelmesi hem teknolojik hem de sektörel açıdan yöndeşmeye neden olmuştur. Sayısallaşma ve bilgisayar teknolojilerindeki gelişmelerin bir yansıması olarak ortaya çıkan yöndeşme, gazetecilik pratiklerinde de önemli değişimleri beraberinde getirmiştir. Özellikle internetin haber üretimi ve sunumu için kullanılmaya başlanmasıyla birlikte gazetecilik alanında, İnternet gazeteciliği, online gazetecilik ve ağ gazeteciliği gibi isimlerle tanımlanan yeni gazetecilik biçimleri ortaya çıkmıştır. Adı geçen gazetecilik türlerinin ortak noktası ise gazetecilerin tek bir ortama ilişkin bağımlılıklarını ortadan kaldırarak, her medya ortamı için haber üretebilmelerini öngörmesidir. Benzer biçimde her geçen gün Türkiye'de hem gelişen talepler hem de yükseköğretim politikaları sonucu iletişim fakültelerinin sayısı artmakta, her yıl sektörün intiyacını aşan sayıda mezun verilmektedir (Karaduman, 2015: 3033). Karaduman, fakültelerin sayısının artmasıyla birlikte aynı zamanda müfredatlarındaki teorik ve pratik ders oranlarının da değiştiğini, bunun da verilen/ kazandırılan formasyon açısından belirli tutarsızlıklara, farklılıklara neden olduğuna vurgu yapmaktadır (2015: 3034). Karaduman'ın bu vurgusuna yönelik olarak öğrencilerin görüşleri de önem kazanmaktadır. Öğrencilerin, gazetecilik eğitiminin asal unsurları oldukları göz önüne alınırsa, mesleğe ve formasyon aldıkları alana ilişkin düşünceleri mutlaka değerlendirmeye alınmalıdır. Sonuç itibariyle teknolojik gelişmeler de göz önüne alındığında bu değişimlerin gazetecilik eğitimine ne kadar yansıdığının, değişimin mevcut pratikler, müfredat ve uygulamalar üzerinde varsayılan etkisinin eleştirel bir biçimde değerlendirilmesinin ne kadar önemli ve acil olduğu ortaya çıkmaktadır.

John V. Pavlik, Yeni Medya ve Gazetecilik isimli kitabında, yeni medya teknolojilerinin gazetecilik ve kitle iletişim eğitimi için önemli çıkarımlara sahip olduğunu belirtir: “(1) yeni medya, gazetecilik ve kitle iletişimini öğretme ve araştırma yolumuzu veya eğitimcilerin işlerini yapma yollarını nasıl değiştiriyor; (2) yeni medya öğrettiklerimizin içeriğini nasıl değiştiriyor; (3) yeni medya gazetecilik ve kitle iletişim okullarını, bölümlerini, üniversiteleri veya diğer yükseköğretim kurumlarını nasıl değiştiriyor ve (4) yeni medya gazetecilik eğitmenleri ve öğrenciler, fon sağlayıcıları, rakipler ve diğerlerinden oluşan kitle arasındaki ilişkiyi nasıl değiştiriyor.” (2013: 303). Bu çalışma da Pavlik'in vurguladığı çıkarımları Tirebolu İletişim Fakültesi Gazetecilik Bölümü mikro ölçeğinde değerlendirmeye yönelik çok temel ve başlangıç düzeyinde bir girişim olarak değerlendirilebilir.

Bu çalışmada da Tirebolu İletişim Fakültesi Gazetecilik Bölümü ${ }^{6}$ ve öğrencileri özelinde hem gazetecilik eğitimini pratik uygulamalarla destekleyen bir girişimi tanıtmakGazetecilik Bölümü Uygulama Atölyesi- hem de bu atölyeye katılan öğrencilerle

6 Bölüm ilk mezunlarını 2018-2019 akademik yılı içerisinde verecektir.

$7 \mathrm{Bu}$ atölyeye katılmak için başvuran, başvurularının değerlendirilmesi sonucu atölyeye dâhil olan, tüm dönem boyunca nitelikli ve disiplinli biçimde atölyeye devam eden ve sonuç olarak da bu çalışmanın ortaya 
yapılan odak grup görüşmeleriyle öğrencilerin mesleğe ve dijital gelişmelere yönelik kavrayışlarını ortaya koymak amaçlanmıştır. Çalışmanın yazarlarının da bu atölyeye doğrudan katkı veren öğretim elemanları olması ve büyük çoğunluğunun gazetecilik bölümünde ders veriyor olması çalışmanın niteliğini eleştirel ve pedagojik bir otoanalize de taşımaktadır. Bu amaçla önce atölye deneyimi, tarihçe, oluşum süreci, ortaya çıkarılan ürünler (Gazete), fakültede mevcut haber ajansıyla (Günimedya) işbirliği gibi başlıklar altında değerlendirilecek, ardından öğrencilerle yapılan odak grup görüşmelerinden ortaya çıkan bulgular serimlenecektir.

Tirebolu İletişim Fakültesi Gazetecilik Bölümü Uygulama Atölyesi'nin kurulmasındaki temel amaç öğrencilere 21. yüzyılın gazetecilik faaliyetleri için temel becerileri kazandırmaktır. Bununla beraber öğrencileri gelecekteki mesleklerine en hazır şekilde mezun etmek ve sektöre donanımlı gazeteciler kazandırmak atölyenin amaçları arasındadır. Fakültedeki etkinliklerin ve derslerin belirli bir sınırlılık (ders saati, yoğun öğrenci sayısı vb.) içinde yapılıyor olması düşünüldüğünde, atölyenin gazetecilik pratiklerini geliştirmede öğrenciler için yeni bir olanak olduğu açıktır.

\section{Gazetecilik Bölümü Uygulama Atölyesi Olușum ve Gelișim Süreci}

Bu aşamadan sonra kısaca Atölye olarak ifade edeceğiz çalışmanın iki önemli süreçten oluştuğunu ifade etmek durumundayız. Oluşum süreci olarak tanımlayacağımız ilk süreç atölyenin daha sonraki gelişim sürecine etki eden kimi özellikler taşıdığından ayrı bir şekilde vurgulanması gerekir. Oluşum sürecinin ana motivasyonlarından biri öğrencileri gazetecilik alanının farklı uzmanlık dallarında uygulamaya dönük örgütlü bir şekilde birlikte çalışma ve ekip üyesi olma becerisini kazandırabilmektir. Diğerleri ise bu çalışmalarını somut üretimlere dönüştürdükleri, daha önce kurulmuş olan Günimedya Haber Ajansı'nı daha nitelikli hale getirmek ile birlikte bir de basılı gazete çıkarmaktır.

Bu bağlamda Arş. Gör. Ali Karakaya, daha önce topluluk ve atölye çalışmalarında edindiği deneyimler ile en uygun çalışma biçiminin bir eğitim-uygulama atölyesi olduğu fikri ile fakülte yönetiminin ve katkı verebilecek öğretim elemanlarının konuyla ilgili onay ve fikirlerini almıştır. Sonuç itibariyle, Doç. Dr. Günseli Bayraktutan, Dr. Öğr. Gör. Barış Yetkin, Öğr. Gör. Nedim Serhat Bilecen ve Arş.Gör. Ali Karakaya ile birlikte Atölye çalışması yol almaya başlamıştır.

Atölyenin nasıl işleyeceği, fiziksel mekânın nasıl düzenleneceği ve atölyeye katılacak öğrencilerinin nasıl seçileceği konusunda yapılan istişareler sonrasında her eğitimcinin takvimine göre haftalık eğitim çalışmaları yapması kararlaştırılmıştır. Ardından teknik intiyaçlar başta olmak üzere (pc, projektör, fotokopi ve baskı makinesi v.b) öğrencilerle eğitimlerin ve toplantıların yürütüleceği eğitim odasının geniş alanlı, tüm öğrencilerin aynı yerde ve birlikte çalışmasını mümkün kılacak masalarla döşeli olarak genel düzenlenişi sağlanmıştır.

Öğrencilerin seçim aşamasında kritik nokta olarak hangi ölçütlere göre seçim 
yapılacağına odaklanılmıştır. Burada akademik not ölçütü olarak 2,50 ortalama, başvuracak öğrencinin kendisini tanıtıp atölye çalışmasından ne beklediğini ve atölyeye neler katabileceğini ifade edeceği bir niyet mektubu ve olası her duruma karşı öğrenci olduğunu beyan eder bir öğrenci belgesi talep edilmiştir.

Dördüncü sınıf eğitimini 2018-2019 eğitim yılında açacak olan gazetecilik bölümü olarak, bir, iki ve üçüncü sınıflarının tümünden başvurular kabul edilmiştir. Atölyeye kabul edilmesi planlanan öğrenci sayısı hem çalışma alanının boyutları, hem eğiticilerin yoğunluk durumu, hem çalışmanın ilk deneyim olmasından ötürü 20 olarak belirlenmiştir. Başvuru mektuplarının okunmasının ardından, adayları değerlendiren eğiticiler, üzerinde uzlaştıkları mektuplar temelinde eleme yaparak 33 öğrencinin mülakata ${ }^{8}$ alınmasına karar vermiştir.

Mülakatlar sonucunda dört kategori üzerinden öğrenci seçimi yapıldı. Bunlar olumlu, olumlu yedek, olumsuz yedek ve olumsuz olarak belirlendi. Bu kategoriler içerisinden on üç öğrenci olumlu, beş öğrenci ise olumlu yedek kategorisinde atölyeye seçildi. Ancak hedeflenen kontenjanı eksik bırakmamak amacıyla önce olumsuz yedekte yer alan dört öğrenciden ikisini eleme fikri ile tekrar değerlendirme yapılırken, aynı kategoride yer almış öğrenciler arasında ayrım yapmamak amacıyla kontenjan genişletilerek dört öğrenci atölyeye kabul edildi ve toplam 22 öğrencinin de belirlenmesi ile atölye oluşum süreci tamamlanmış oldu.

Bu sürecin ardından aşağıda bahsedilen gelişim süreci ve aşamaları gerçekleşmiştir ve atölye ciddi bir yol almıştır. Burada üç etki söz konusudur. Illk olarak baştan beri birlikte istişare ve uzlaşarak karar alma ilkesi her zaman atölyenin işleyişine hâkim olmuştur. İkinci olarak öğrencilerin eğitim ve uygulama süreçlerinde her zaman onlara da danışılarak ve talepleri göz önünde bulundurularak belirlenen ölçütlere göre hareket edildi. Bununla birlikte atölyenin tüm gelişim ve işleyiş süreci, yaşanan sorunlar, eksiklikler ve kimi zaman maruz kalınan zorunluluklar da dahil olmak üzere her zaman atölyenin tüm bileşenlerine, katılımcılarına ve çalışılan kişilerine açık, şeffaf bir şekilde işletilmiştir.

\subsection{Uygulama Gazetesi}

Atölye, yazı işleri ve tasarım birimi olmak üzere iki ana yapıdan oluşmaktadır. Kurucu Komisyon tarafından bu birimlerde görev almak isteyen öğrencilerin başvurularında yukarıda da aktarıldığı üzere gerek niyet mektuplarının değerlendirilmesi gerekse

\footnotetext{
8 Sabah 11.00 saatlerinde başlayan mülakatlara 2 öğrenci dışında tüm öğrenciler katılmıştır. Mülakatta atölye çalışmalarını yürütecek olan dört öğretim elemanı ile birlikte bölüm başkanı Dr. Öğr. Gör. İsmail Cem Feridunoğlu da yer almıştır. Rastgele sıra ile mülakata çağrılan öğrencilere her biri bir hoca tarafından sorulan üzerinde uzlaşılmış sorular yanında öğrencilerin anlatımlarına göre șekillenen kimi sorular da sorulmuștur. Ortak sorulan sorular, öğrencinin mesleğine yönelik hedeflerinin ne olduğu, alanın hangi kolunda ve neden uzmanlaşmak istediği, kendisine rol model olarak gördüğü alandan veya alan dıșı kişiler olup olmadığı ve onlar hakkındaki bilgi/fikirleri, çalışmaların gerektireceği sorumlulukları mümkün olduğunca yerine getirmede gönüllü olup olmadıkları sorulmuştur. Her öğrencinin mülakatının ardından hocalar öğrencinin performansına göre uzlaştıkları bir karara vardıktan sonra diğer öğrenci mülakata çağrılmıştır. Bununla da ilk giren öğrencinin sonlara doğru net hatırlanmaması ve değerlendirilememesine dair kaygının giderilmesi amaçlanmıştır.
} 
mülakat süreçlerinde titiz bir çalışma yapılmıştır. Öğrencilerin seçimi sırasında Anadolu Meslek Lisesi mezunu olup grafik tasarım eğitimi almış kişilerin tasarım ekibine dâhil olması sağlanmıştır. Değerlendirmeler sonucunda üçüncü sınıflardan dört ve ikinci sınıftan bir kişi olmak üzere tasarım ekibi oluşturulmuştur.

\section{Eğitim Aşaması}

Dijital teknolojinin gelişimine paralel olarak, özellikle medya sektöründe multimedyanın etkin olması, Atölye etkinlikleri bünyesinde yer alan tasarım eğitiminin önemini arttırmaktadır. Yazı işleri ve tasarım ekiplerinin oluşturulmasının ardından, eğitim çalışmalarına başlanmıştır. Diğer atölye eğitim konularının yanı sıra tasarım eğitimine ilk seminerlerde tüm öğrencilerin katılmaları sağlanmıştır.

Tasarım ekibi ve diğer katılımcılara yönelik kuramsal, teknik ve uygulama eğitimi çerçevesinde ortak bir seminer düzenlenmiştir. Seminerde, masaüstü yayıncılık, tasarım, renk yönetimi, tasarımın önemi ve işlevleri haber olgunun yapısı, unsurları, haberin tasarımı gibi konu başlıklarını taşıyan bilgiler aktarılmıştır. Muhabirlerin haberlerini oluşturmakta kullandıkları metin, fotoğraf, grafik, vinyet özellikleri, ajans haberleri ile gazete haberleri arasındaki farklılıklar gibi tasarım sürecinde sayfa sekreterlerinin ihtiyaç duyacakları unsurlara özellikle vurgu yapılmıştır.

Sonraki seminerlerde masaüstü yayıncılık ve sayfa tasarımı kuramsal ve uygulama eğitimleri verilmeye başlanmıştır. Photoshop, Quarkxpress, Indesign grafik tasarım programlarının temel kullanımının ve temel tasarım ilkelerinin yanı sıra yaratıcılığın özgürleşmesi yoluyla özgünleşmesi sağlanmaya çalışılmıştır.

\section{Hazırlık Aşaması}

Gazetenin deneme sayısının yayımlanma tarihi, Tirebolu İletişim Fakültesi'nin aynı zamanda mezuniyet töreni tarihi de olan, 9 Mayıs 2018 olarak belirlenmiştir. Deneme sayısının hazırlanması kararının alınmasıyla birlikte, basımın ve dağııımın yapılacağı tarihe kadar bir haftalık çalışma süresinde tamamlanması gerekmiştir. Yayımlanma tarihine kadar olan bu süre, tasarım ve basım çalışmalarında herhangi bir teknik sorun yaşanmaması durumunda zamanın yeterli olacağı varsayılmıştır.

Tasarım çalışmaları için gerekli teknik ve iletişim altyapısı oluşturulmuştur. Atölye çalışmaları için örgün grafik tasarım eğitimleri için kullanılmakta olan Macintosh bilgisayar laboratuarından yararlanılmıştır. Grup içi haberleşme, Whatsapp, e-posta; Günimedya haber ajansı ve yazı işleri haber akışı ise, NAS sunucusu üzerinden oluşturulmuş olan bulut sistemiyle sağlanmıştır.

\section{Tasarım Aşaması}

Süreç içerisinde Özel Sayı adı altında bir deneme sayısının hazırlanması ve yayımlanması önemli görülmüştür. Her süreli yayın için prototip düşüncesiyle bir deneme 
sayısının ortaya çıkardığı birçok işlevden söz edilebilir: bir süreli yayının tasarımsal olarak çizilmesi, ortaya çıkabilecek öngörülmeyen teknik sorunların belirlenmesi, tasarımcıların eğitimi, çalışma disiplinlerinin anlaşılması, basımı gerçekleştirecek matbaanın gerçekleştireceği basım becerisi ve kalitesi vb. Ancak belki de en önemli işlevin, simülasyon biçiminde uygulama eğitimi olduğu belirtilmelidir.

Tasarım çalışmaları süresince çeşitli sorunlarla karşılaşılmıştır. Öncelikli sorunlardan biri, gazete adının ne olacağının uzun süre belirlenememesi ve bu nedenle de gazete başlığının (logotype) tasarımının gazete sayfa düzeni sürecinde yapılmasını gerektirmesidir. Bu durum, tasarımın ekibinin alternatif başlık tasarımlarını ve sayfa tasarımlarını eş zamanlı gerçekleştirmesini gerektirmiştir. Gazete bünyesinde görev dağılımının tam yapılmamış olması ya da bir diğer deyişle son anda belirlenmesi, Atölye'nin iç işleyişine yönelik çeşitli sorunlara da neden olmuştur. Bu sorunlar, ilgili kişilerin çalışmalara katılamaması; yazı işlerinin yayınlanacak haberleri tam olarak belirlememesi, haberlerin editoryal süreçten son dakika geçmesi, yazıların ve haberlerin tasarım süreci içinde gecikmeli olarak ulaşması; sayfa sekreterlerinin çalışma disiplini ve tekniğine alışık olmaması olarak sıralanabilir. Tüm bunların yanı sıra, teknik sorunlar da (İnternet erişiminin sağlıklı olmaması, bulut üzerinden haber akışının kesilmesi vb.) söz konusu olmuştur.

\section{Basım aşaması}

Fakültenin şehir merkezinden uzak bir ilçede olması uygun bir matbaanın bulunmasını, iletişime geçilmesini ve de basım işinin zamanında yetiştirilmesini zorlaştırmıştır. Ancak, tasarımın aşamasında şehir merkezinde bir matbaa ile anlaşma sağlanabilmiştir. Basımı gerçekleştirecek matbaaya tasarım elden dijital olarak verilmiş ve ilk sayı olması nedeniyle talep edilen özellikler doğrudan belirtilmiştir.

Tüm bunlara karşın program uyumsuzluğu nedeniyle yarım günlük bir gecikme yaşanmıştır. Söz konu matbaa, gazetenin deneme sayısının basımını iki gün içinde gerçekleştirmiş ve teslim tarihine yetiştirmiştir (Bkz. Görsel 1). Ancak çeşitli nedenlerden kaynaklandığı anlaşılan gazetenin basım kalitesi beklentinin çok altında kalmıştır.

Yaşanan tüm bu sorunlar, gazetenin ilk sayısının hazırlık sürecinde öğretici olmuştur. Teknik ön hazırlıkların tekrar gözden geçirilmesi, benzer sorunların tekrar yaşanmaması sağlanması için önlem alınması gerekmektedir. 

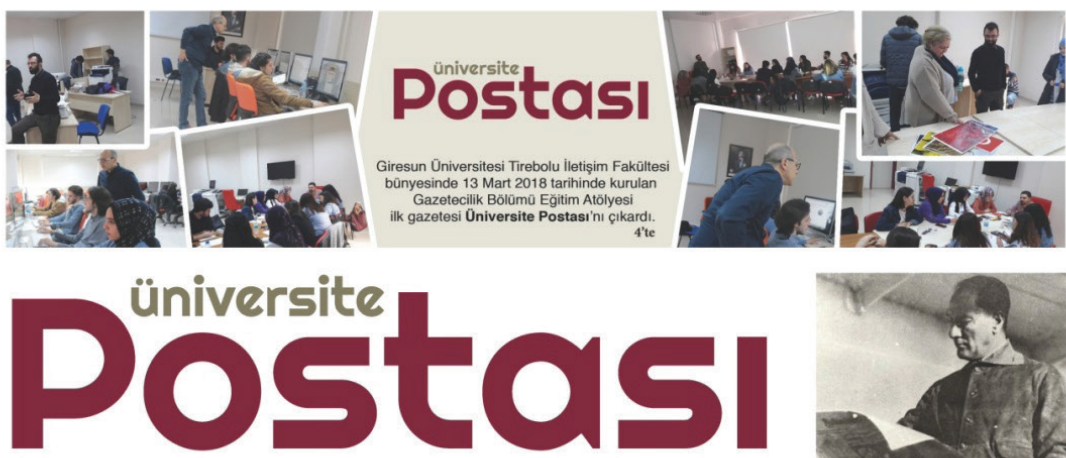

(:) Tirebolu Iletişim Fakültesi Uygulama Gazetesi

Mayıs 2018 / Özel Sayı

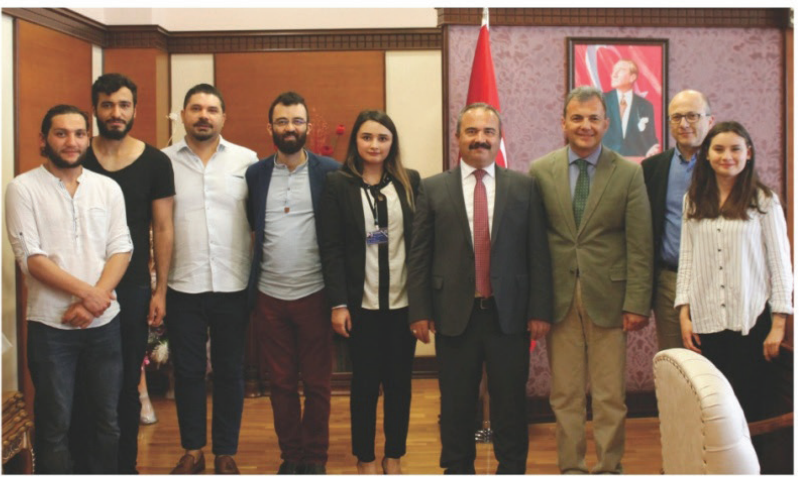

Rektör Prof. Dr. Cevdet Coşkun: "iletişim Fakültesi gözbebeğimiz"

Tirebolu İletisim Fakültesi Gazetecilik Bölümü Eğitim Atölyesi, Giresun Üniversitesi Rektörü Prof. Dr. Cevdet Coşkun'la üniversite, eğitim ve iletişim üzerine bir söyleşi gerçekleştirdi.
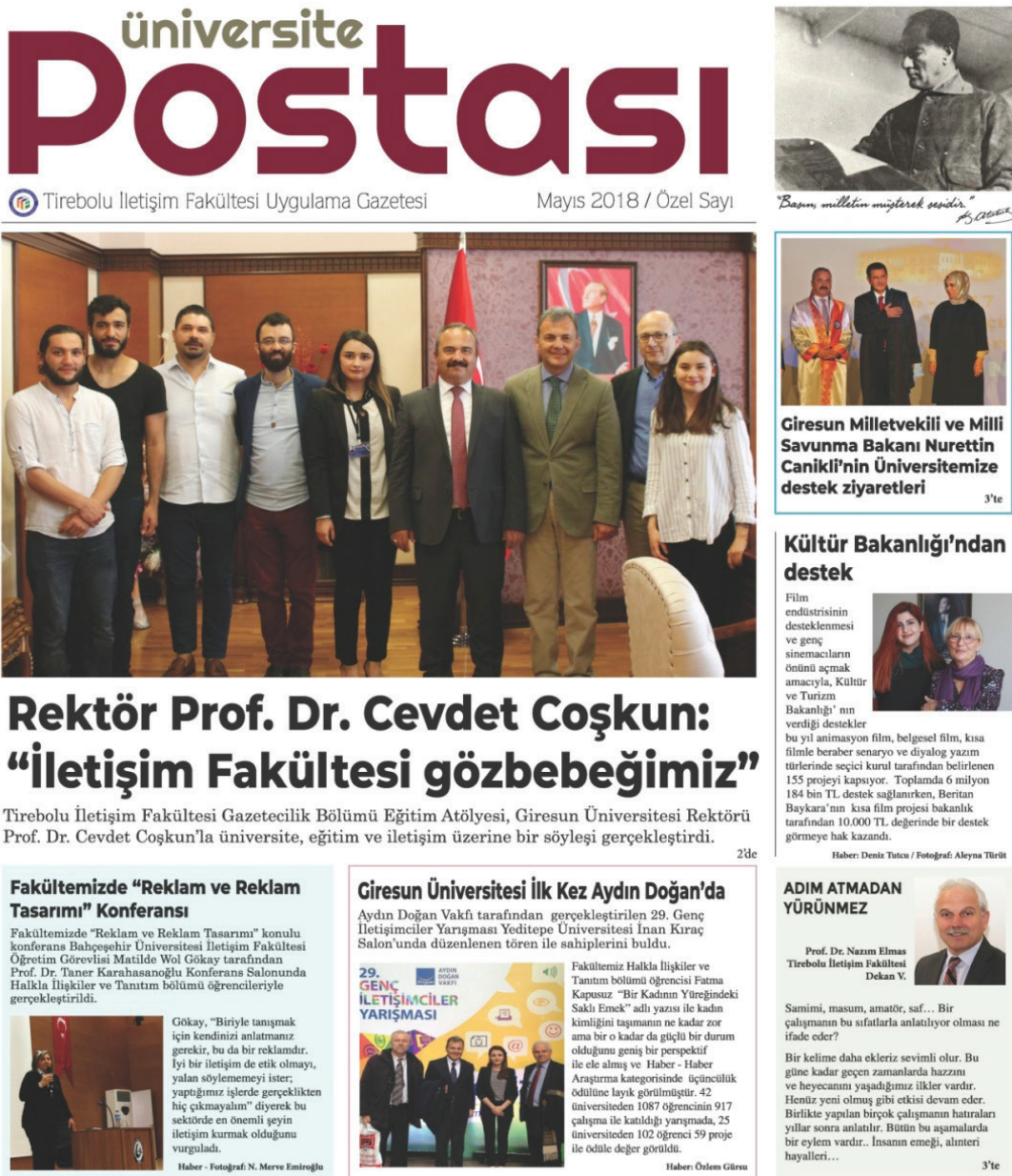

Kültür Bakanlığı'ndan destek

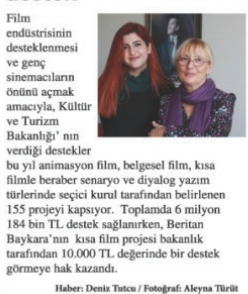

ADIM ATMADAN YÜRŨNMEZ

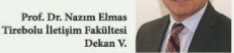

Samimi, masum, amator, saf... Bir çalşmanin bu sifatarla anlathlyor olmass ne

Bir kelime daha ekleriz sevimli olur. B gunc kadar gecencn zamanlarda hazzini Henüz yeni olmus gibie etkisi devam eder. yillar sonra anlathir. Butun bu aşamalard hayalleri...

Görsel 1. Üniversite Postası Mayıs 2018 Özel Sayısı - Kapak

\section{Günimedya'ya Katkıları}

Günimedya Gazetecilik Bölümü öğrencilerinin habercilik pratiklerini geliştirmek ve çağın getirdiği habercilik anlayışına uyum sağlamak amacıyla 2017 yılında (Giresun 
Üniversitesi Medya) ismiyle uygulama haber ajansı olarak faaliyete geçmiştir. Ajansın öncelikli misyonu, Gazetecilik Bölümü öğrencileri için derslerde teorik olaraköğrendikleri gazetecilik mesleğini, profesyonel bir ortamda uygulayabilecekleri olanakları sağlamak olarak ifade edilebilir. Ayrıca üniversite hakkındaki bilgi ve gerçekleşen çalışmaların haber içeriklerinde yer alarak kayıt altında tutulması ajansı aynı zamanda güncel bir arşiv haline de getirmiştir. Haber ajansı ile gazetecilik atölyesinin birleştiği nokta ise, ajansın sürekliliğini sağlayacak ve her sene yeni gelen bölüm öğrencilerine deneyimlerini aktaracak çekirdek bir öğrenci kadrosunun oluşturulmasıdır.

Kabul mektubu ve mülakat aşamasından geçen 22 öğrenci ile yapılan alandan bilgi toplama, haberleştirme ve etkinlik izleme gibi muhabirlik süreçleri eğitimi hem gelişimlerini hem de ajansta yer alan haberlerin niteliğini olumlu yönde etkilemiştir. Bununla beraber atölyede rutin olarak yapılan haber toplantıları da, öğrencilerin profesyonel mesleğe geçişlerinde önemli bir tecrübe eksikliğini gidermiştir. Atölye çalışmaları boyunca gözlemlenen olumlu gelişmeler aslında yapılan bu çalışmanın öğrenciler üzerinde ne kadar olumlu etkiler bıraktığını ortaya koymuştur. Örneğin 22 kişilik atölye grubunun içerisinde henüz 1.sınıfta olan 4 öğrenci, herhangi bir haber toplama ve yazma dersi almamışken atölyede aldıkları haber eğitimi ile kendilerine ait birçok habere imza atmışlardır. Habercilik pratiklerinin gelişimi yanında ayrıca atölyenin pedagojik anlamda da artıları olmuştur. Fakülte etkinlikleri ve derslerde oldukça çekingen bir tutum sergileyen 4 öğrenci, verilen eğitimlerden sonra daha aktif hale gelmişlerdir. Özellikle yönlendirilen olaylarda haber kaynakları ile görüşmek ve elde edilen bilgileri haberleştirmek konusunda oldukça başarılı olmuşlardır. Bu noktada etkin olan unsurlardan bir diğeri de, emek verdikleri haberlerin ajansta kendi adlarını taşıyarak yayınlanmasıdır. Yayınlanan her haberden sonra öğrencilerin ilgilenme düzeyleri gözle görülür şekilde artmış ve artık öğrenciler haber konularını da kendileri bulmaya başlamıştır.

Gazetecilik atölyesinin haber kısmı ile ilgili verilen eğitimlerin amacı aslında gazetecilik yapmayı hedefleyen öğrencilerin teşvikini sağlamaktı. Bu anlamda atölye amaçladığı başarıya ulaşmıştır. Özellikle haber kaynağına ulaşma, bilgi toplama, metinleştirme ve röportaj konusunda oldukça başarılı işlere imza atılmıştır. Gazetecilik merak, arzu ve süreklilik isteyen bir iştir. Etrafında olup biteni görmeyen veya gündemi takip etmeyen bir kişi gazetecilik yapamaz. İstekli ve ısrarcı olmak burada kilit noktadır. Gazetecilik atölyesinde de biraz bu tespitler görülmüştür. Başlangıçta atölyeye katılan herkes meraklı ve istekli görünürken zaman ilerledikçe bu istek ve kararlılıklarını devam ettirenler sayısı gittikçe azalmıştır. Kendilerini haberin farklı alanlarında yetiştirmek isteyen öğrenciler de olacaktır. Ancak şu bir gerçek ki haberin ana yapısını bilmeden gazetecilik mesleğinin herhangi bir alanında çalışmak oldukça zordur. Sonuç olarak yaklaşık üç ay süren gazetecilik atölyesinin haber eğitimi kısmı öğrencilerin habere ilişkin temel değerleri öğrenmeleri, haber toplama- yazma ve becerilerini geliştirme noktasında oldukça verimli geçmiştir. Atölyede diğerlerine göre daha başarılı olan öğrenciler, haber ajansının omurgasını ve yakın zamanda çıkması planlanan üniversite gazetesinin ana kadrosunu oluşturacaklardır. 


\section{3. Öğrencilerin Gözünden Gazetecilik Mesleği Ve Alandaki Dijital Gelișmeler}

Çalışmanın bu bölümünde araştırmaya dâhil olan öğrencilerin gazetecilik mesleği bağlamında gelecek için beklentileri, geleceği nasıl çerçeveledikleri, mesleği nasıl anlamlandırdıkları, dijital çağda gazetecilik tartışmalarına egemen kavramları ve süreçleri nasıl değerlendirdikleri (örn. veri gazeteciliği, kitle fonlu gazetecilik, kullanıcı türevli içerik vb.) ve etik tartışmasını yeni medya dolayımlı nasıl kavradıklarına ilişkin tartışmaları içermektedir.

\subsection{Yöntem}

Çalışmada niteliksel bir araştırma yönelimi/ kavrayışı hâkimdir. Nitel bir araştırma yaklaşımının benimsendiği bu çalışmada uygulamada kullanılan teknikler birbiriyle etkileşime geçmeyen, geçirgen olmayan kategoriler ve sonuçlar üretmez. Bir özel olay olarak Atölye'nin öyküsünün çalışıımasını, hem bir durum çalışması olarak tanımlıyoruz (Glesne, 2013: 30) hem de tıpkı Glesne'nin tercih ettiği biçimiyle (2013: 26) "hem yorumlamacı hem de nitel terimlerinin yerine geçecek bir biçimde insanların gerçekliği nasıl yapılandırdıklarını, davranışlarını ve bakış açılarındaki biricikliği ve örüntüleri yorumlamayı amaçlayan uygulamaları adlandırmak için" etnografyayı kullanıyoruz. Çalışma aynı zamanda Atölye deneyimini hikayelendirmesi bağlamında bir kuruluş monografisi olarak da değerlendirilebilir. Aziz'e göre kuruluş monografilerinde "ele alınan kurum ya da kuruluşun bir portresi, biyografisi ortaya konmaya çalışılır" (2003: 78). Bu bağlamda bu çalışma da bir tür Atölye biyografisi de içermektedir.

Çalışmada Atölye'de görev alan öğrencilerin gazetecilik mesleğine ve meslekteki dijitalleşme süreçlerine ve ortaya çıkan görünümlere dair düşünce ve tutumlarını öğrenmek hedeflenmiştir. Mayring'in de ifade ettiği üzere tüm bunlar güçlü biçimde sosyal bağlantılarla ilgilidir ve araştırmanın bu anlamda sosyal grup içerisinde yapılması önemlidir (2011: 82). Mayring, grup tartışmalarının- odak grup kastediliyorözellikle "kolektif düşünce, ideoloji ve önyargıların araştırılmasında" uygun olduğunu vurguluyor (2011: 84).

Bu bağlamda grup tartışmaları açısından özel bir teknik olan odak grup tekniği tercih edilmiştir. Odak grup, "seçilmiş bir grup bireyle onların bir konu hakkındaki görüşleri ve deneyimleri hakkında enformasyon sağlamak için yapılan organize tartışmayı" içerir (Gibbs 1997'den akt. Kuş, 2007: 102). Odak grup tekniğinin tercih edilme nedenlerinden en önemlisi de tekniğin etkileşime dayalı gerçekleştirilmesidir. Etkileşim, "katılımcılara birbirlerine sorular sorma ve kendi özel deneyimlerine ilişkin anlamalarını tekrar gözden geçirme ve yeniden düşünme imkânı” vermektedir (Kuş, 2007: 103). Bu bağlamda odak grup görüşmesine katılanların birlikte çalışma ve üretme deneyimine sahip bireyler olması aralarındaki etkileşimi de olanaklı kılmış, odak grup amacına ve beklentiye uygun biçimde gerçekleştirilmiştir.

Öğrencilerin mesleğe, geleceğe ve teknoloji dolayımlı gelişmelere yönelik bakış açılarını öğrenebileceğimiz iki odak grup görüşmesi fiziksel olarak atölye ortamında 
ve 2018 Haziran ayı içerisinde gerçekleştirilmiştir. Bu kapsamda çalışmaya katılacak öğrenciler atölyeye devam eden ve nitelikli katılım/ katkı sağlayan öğrenciler arasından seçilmiştir. Öğrenciler öncelikli olarak sözlü bilgilendirilmiş, daha sonra çalışma öncesinde de yazılı onanmış rızaları (Araştırma Gönüllü Katılım Formu) alınmıştır. İki odak grup görüşmesinin ilkine 7, ikincisine ise 6 öğrenci katılmıştır. Görüşme boyunca izinli olarak ses kaydı alınmıştır, daha sonra bu ses kayıtları yine grup içerisinden katılımcı öğrenciler tarafından deşifre edilmiştir. Öğrencilere sözü geçen başlıkları içeren sınırlı sayıda soru yöneltilmiştir, bunun dışında yaş ve cinsiyetle birlikte önceki eğitim (anadolu lisesi, meslek lisesi vb.) ile ailelerinde medya mensubu olan/gazetecilik yapan/ okuyan birileri olup olmadığı da sorulmuştur.

Odak grup görüşmeleri esnasında moderatör dışında diğer araştırmacılar gözlemci olarak katılmışlar, böylece grup dinamiklerinin, katılımcı tepkilerinin ve göz ardı edilebilecek diğer tartışma ve ayrıntıların dikkate alınmasını sağlamışlardır. Her oturum sonunda moderatör ve gözlemciler grup tartışmasını değerlendirmişlerdir, dikkat çekilmesi gereken vurgular ortaya konulmaya çalışılmıştır. ${ }^{9}$

$\mathrm{Bu}$ çalışmada benimsenen ve uygulanan odak grup çalışmasında aşağıdaki temalar odağa alınmıştır. Bu başlıkları içerecek sorular yöneltilmiştir:

- Gazetecilik bölümlerini tercih nedenleri, etkili süreçler ve kişiler

- Gazetecilik mesleğine yönelik kavrayışları, işlevlerine ilişkin görüş ve düşünceleri

- Gazeteciliği tanımlayan temel ilkeler

- Dijitalleşmenin/ yeni medyanın gazetecilik alanına etkileri, olumlu ve olumsuz yönleri

- Dijitalleşmenin gazetecilik etiğine yönelik etkisini

- Veri gazeteciliği, robot gazetecilik, kullanıcı türevli içerik, kitle fonlu gazetecilik konularındaki görüşleri

- Yurttaş gazeteciliği hakkındaki düşünceleri

- Geleceğin gazetecisinde olması gereken özellikler

\subsection{Bulgular}

Odak grup görüşmelerine katılan öğrencilerin 11'i kız, 2'si erkek öğrencidir. Geldikleri iller, Giresun, Afyon, Samsun, Trabzon, Kars, Hatay gibi farklı bölgelere dağılmıştır. Alınan önceki eğitimlerde ise yine çeşitlilik hâkimdir, endüstri meslek lisesi, Anadolu lisesi, imam hatip lisesi gibi farklı türde liselerden gelen öğrenciler söz konusudur. Öğrenciler içerisinde ilk ve tek tercih olarak bu bölüme gelen öğrenci de var, farklı alanları tercih edip puanlama nedeniyle bu bölüme gelen öğrenciye de rastlamak mümkündür.

“...Samsunluyum, Imam Hatip Lisesi çıkışlıyım. Illk tercihim, tek tercihim.” (K2 $\left.{ }^{10}\right)$ “...Karslıyım Kars'tan geldim. Mesleki ve Teknik Anadolu Lisesi

9 Bu çalışmada Günseli Bayraktutan moderatör, Barış Yetkin, Nedim Bilecen ve Ali Karakaya gözlemci olarak görev almışlardır. Görüşmelerin her ikisi de 60 dakika sürmüştür.

$10 \mathrm{~K}$, kadın, E, erkek. 
mezunuyum. Aslında çocuk gelişimciydim ama olmadı. Üçüncü tercihim burasıydı, ilk tercihim kendi bölümümle alakalıydı, onlar olmayınca buraya geldim." (K5)

Öğrencilerin bir kısmı da tüm tercihlerini medya ve iletişim alanında yapmışlardır.

"Yedinci sıradaydı. Ama hepsi yine iletişim fakültesiydi. Yani Evet medya alanında geldim (gülümsüyor. Medya alanında çalışmak istiyordum, o yüzden." (K11)

Bazı öğrencilerin ailelerinde örnek aldıkları medya sektöründe çalışan yakınları var, ancak çoğunluğunun ailede bu alanlarda çalışan bir yakını yok.

"Dayımın radyosu vardı, küçükken de arada bir böyle kaçamak yapıp gidiyorduk. Bir kere beni yayına aldı, 12-13 yaşlarındaydım. Mikrofon önünde konuşmaya başladım, gel zaman git zaman artmaya başladı sürekli gitmeye başladım." (E1)

\section{Rol modelleri- örnek aldıkları kişiler}

Öğrencilerin medya sektöründe örnek aldıkları isimler hem TV sektöründen hem de ilgilendikleri özel bir alt alandan (spor basını) olabildiği görülmüştür.

"Şöyle söyleyeyim, hani bizim haberlerle büyüdüğüm için Mehmet Ali Birand'la Ali Kırca hani onun haberiyle büyüdüm." (K4)

"Meslekte, spor anlamında sporla ilgileniyorum. Beşiktaş takımını tutuyorum. Muhabiri var Fırat Güner, Hakan Gündoğan var. Meslek dışına çıkarsak onu da sorarsanız Elon Musk derim mesele teknolojik gelişmeleri takip etmeyi seviyorum." (E2)

"Çoğunu takip ediyoruz. Ama hani hep böyle şu da rol model olabilecek değdim kişiler yok. Çünkü görüşlerinin bazılarını sevdiğim bazılarını sevmediğim yönleri oluyor. Bu da onları tam anlamıyla takip etme konusunda çelişkilere düşürüyor bazen beni. Bu yüzden kişiyi takip etmiyorum." (K10)

\section{Gazetecilik mesleğini kavrayışları}

Gazetecilik mesleğine yönelik olumlu ve olumsuz kavrayışlar bir arada ifade ediliyor, en çok vurgulanan özelliği "zor bir meslek" olması.

"Bence zor ve adaletsiz bir meslek. Çünkü herkes haktan, 
hukuktan ve adaletten bahsediyor ama hiçbir zaman gazeteciler tam anlamılla bunları dile getiremiyor bence." (K1)

"Hocam biraz da hatayı kabul etmeyen bir meslek. Yani her konuda bilgi sahibi olması gerekiyor hem bölüm içinde hem de yazılan herhangi bir metin açısından bütün bilgiye hâkim olup o şekilde sonuç vermek gerekiyor." (K3)

"Zor bir meslek aslında, bir de önümüzü kapatanda kapalı olanda bir meslek. Hani biz bu bölümü okuyoruz ama bu bölümü okumayan insanlarda gazetecilik yapmaya çalışıyor. Bu da bize bir dezavantaj oluyor." (K5)

"Gazetecinin herkesle iletişim kurabilmesi gerekiyor, herkese hitap edebilmesi gerekiyor. Hem baskı altında kalmaması gerekiyor katılıyorum ama baskı altında kalmayarak, üstteki kişiyi de anlayabilmesi gerekiyor. Alttaki kişiyi de anlaması gerekiyor. Bir de yerinde kullanmak gerekirse yırtık olmak gerekiyor bence."(K9)

Aynı zamanda tarihe tanıklık etmek olarak tanımlanan/ tariflenen deneyim de olumlu bir boyut olarak ifade ediliyor.

"Tarihi yaşayarak yaşıyorsun. Dışarıdan izleyici olarak değil, gerçekten o an ne oluyorsa onun içindesin, hepsine tam olarak uzanabiliyorsun, gidebiliyorsun." K10)

Öğrenciler aynı zamanda ülke koşullarında görev yapmanın, mesleği gerçekleştirmenin zorluklarına da değinmişlerdir.

"Yaptığımız iş, meslek işlev açısından gerçekten çok kıymetli, hani inşaları bilgilendiriyoruz, aydınlatıyoruz. Ama o hak ettiğimiz değeri görüyor muyuz? Burada tartışmalar var. Bence görmüyoruz, ya buna örnek olarak tutuklanan gazeteciler ülkemizde olsun dünyada olsun buna örnek verebiliriz."(E2)

\section{Mesleği tanımlayan temel ilkelere dair görüşleri}

Mesleği tanımlayan temel ilkeler sorulduğunda çoğunlukla gazetecinin bireysel olarak konumuna ilişkin vurgular dikkat çekiyor. Bunlar çoğunlukla nesnellik ve özgürlük olarak ifade edilmekte.

"Ben hala nesnellik konusundayım. O sağlandığı sürece bana göre diğer kalan ilkeler kendini oturtacaktır yerine. Önemli olan orada bir gazeteci olarak nesnel olmak, doğru olmak, 
tarafsız olmak. Tarafsız olduktan sonra illaki bir noktadan sonra beğenileceksin." (E1)

"Zaten temel ilkeleri olarak öğrendik dürüstlüğü.” (K2)

"Özgürlük bence. Yani şöyle ki; Bir gazetecinin birey olması lazım evet ama her şeyden önce özgür olması gerekiyor. Çünkü o kişi topluma bir şekilde bazı olaylar hakkında bilgi vermek durumunda, mesleği bu. Bunu özgür olmadığı süreç içerisinde yapamaz. Kalemi ya da fikirleri özgür olmadığı sürece, istenilen şeyleri sunduğu sürece bunu toplumu bilgilendirmenin bi anlamı olmaz diye düşünüyorum. Yani gazeteci özgürce fikirlerini, düşüncelerini yazdığı sürece gazeteci olabilir bu süre içerisinde toplumu bilgilendirebilir bence. Hem gazeteci için hem toplum için." (K8)

\section{Dijitalleşme sürecine ilişkin kavrayışları}

Dijitalleşme sürecine dair de öğrenciler büyük çoğunlukla olumsuz görüşler ifade etmişlerdir. Özellikle sosyal medyaya ilişkin vurgu belirgindir. Meslek bağlamında gazeteciliği bir meslek olmanın dışına çıkaran ve sıradan her bireyin gerçekleştirebileceği bir eyleme dönüştürdüğüne ilişkin bakış açısı önemlidir.

"Hocam olumsuz etkiler daha çok bence. Çünkü yapılan bir haberde doğruluk payı doğru olma payı azalmaya başladı. Bununla ilgili teyit.org gibi siteler, bir haberin doğruluğunu teyit etmek için kullanmamız gereken siteler ortaya çıktı. Hani artık bir güven ortamı yok, güven sağlanamıyor.” (K1)

"Olaylara daha çabuk hâkim olmamızı da sağlıyor. Facebook olsun, Twitter olsun hani haberlere, olaylara daha çabuk ulaşabilmemizi sağlıyor. Ama her gelen haberin doğru olduğunun garantisi yok zaten ki halkımızda mesela bunu gördüğü zaman doğru gözüyle bakıyorlar öyle bir yanıltmaca olabiliyor. Bunun doğruluğunu teyit etmemiz gerekiyor, direkt hemen inanmamamız gerekiyor. Bu konuda bir tedbir alınması gerektiğini düşünüyorum." (K5)

"Olumlu etkileri var ama olumsuz etkileri de var. Ben olumsuz etkilerini söylemek istiyorum. Hani artık çok fazla herkes bir şeyler hakkında haber yapabiliyor. Bu bölümü okumamışsa olsak herkesin gazeteciliğin alanı ile ilgili mutlaka yaptığı işler oluyor. Mesela sokakta kediye yapılan bir zulmü görüyor ve haberleştiriyoruz. Tabii ki teknik olarak haberleştirmemiş olsa da o haber niteliği oluyor haberci gözünde. Sen onu haber 
metni şeklinde çevirebilirsin. Artık bireysel unvan değil bence. Gazetecilik herkesin yaptığı bir işlem gibi. Meslek olmanın dışına çıkmış gibi hissediyorum daha çok." (K10)

"Aslında böyle yaygınlaştığı için sıradanlaşıyor. Haber bir nebzede yani dijitalleşmenin belki de bu sıradanlaşmaya en büyük etkisi bu olabilir. Bir telefonla atıyorum Twitter'da gezerken karşımıza çıkan bir haberi paylaşıyoruz. Biz paylaşıyoruz bizden görüyor başkası paylaşıyor, başkası, başkası derken artık haber yani her gün böyle paylaşırsak aynı konudaki bir haberi sıradanlaşıyor. Sadece Twitter'da da değil mesela bir haber sitesinde okuduğumuz haberi de sosyal medya platformunda paylaştığımızda öyle yani mesela önceden böyle bir şey olma var mıydı? Hani medyanın bu kadar yakınımızda olmadığını düşünürsek belki de o yüzden sıradanlaşmıyordu haberler daha önce." (K8)

\section{Gazetecilik alanındaki yeni kavramlara ilişkin bakış açıları}

Öğrencilerin alana ilişkin yeni tartışmalara (robot gazetecilik, kitle fonlu gazetecilik, veri gazeteciliği vb.) vakıf olmadıkları anlaşılmaktadır. Özellikle robot gazeteciliğe dönük kavrayışları popüler medyada yer alan robot temsilleri üzerinden şekillenmekte ve yapay zeka ve algoritma tartışmaları hiç anılmamaktadır.

"Bu robot gazetecilik aslında artık insanları geri plana atmış oluyor. Bütün şeyi artık o robotlar tarafından yürütülüyor. Hem mesleğin önü kapanmış oluyor hem de artık daha fazla araştırıp insanlara bir şey katmanın önüne geçmiş olduğunu düşünüyorum." (K5)

Aynen onların açıklamalarını eğer şey yapabilirsek, yani ben karşılaşmadım o tür şeylerle artık yeni geldim diye mi, [...] Hoca'dan ders almadım diye mi, bilmiyorum. Artık da hani karşılaşmadım. (E1)

"Şu açıdan olabilir teknoloji gelişiyor teknoloji geliştikçe robotlar odur budur bir sürü şey gelişiyor. Insan gücüne ihtiyaç azalıyor aynı bir fabrika gibi düşünelim bunu zaten bir bilgisayar yapabilirse bir iş veren hem insan dırdırıyla uğraşıyor hem de insanların derdi çok oluyor sigorta yapacak onu yapacak bunu yapacak alır bir makine nasılsa aynısını o da yapacak. Bence bu meslekte ölebilir." (K9)

"Çünkü robotun düşünce ve duygusu yok. Haberde duygu katılması gereken ya da görüş gerektiren bir haberse bir 
robotun kendi görüşünün olabileceğini düşünmüyorum." (K10)

\section{Herkes bir gün gazeteci olacak mı?}

Özellikle yurttaş gazeteciliği tartışmaları bağlamında araştırmaya katılan öğrenciler mevcut medya yapısı içerisinde özellikle inbar hatları dolayımıyla gerçekleştirilen enformasyon aktarım sürecini eleştirel bir gözle değerlendirmekte ve bu türden pratiklerin haberin neliğine ilişkin ciddi tartışmalar geçirmesi gerektiğini ifade etmektedirler.

"Evet zaten hani kısmen şu an da öyle değil mi? Hani Whatsapp ihbar hatları bu tarz şeyler olsun şu anda var. Bir kaza olduğu zaman gazeteci veya televizyon habercisinin olaya gitmesine gerek kalmıyor çoğu zaman. Olay yerinden geçen vatandaş çekimini yapıp gazeteciye, haber ajansına veya televizyon kanalına bunu yollayabiliyor. Zaten bu bağlamda şu anda da gazeteci olmasına gerek duyulmuyor bir haber yapılması için." (E1)

"Mesela bir kanalı açtığımızda örneğin Show Haber'i orada genelde Whatsapp'tan gelen haberlerle bir saati dolduruyorlar, insanın ilgisini çekmiyor, bu basit haber diyor ya da tabii $k i$ de hani önemli bir olay da olmuştur ama izleyen halk böyle hani... Şu an ifade edemedim ama haber var haber var derler ya. Yurttaş gazeteciliği bir yerden sonra haberin niteliğini düşürüyor." (K4)

"..bildiren kişi olabilir ama gazeteci olmamalı. Sonuçta biz bir eğitim alıyoruz, bazı ilkeler öğreniyoruz fakat orada 'yurttaş gazeteciler' dediğimiz kişiler bu ilkeleri yansıtmadan, öğrenmeden görüntü, fotoğraf çekiyorlar. O ilkeleri bilmeden o sıfatı vermek..." (E2)

Benzer bir çalışma 2011-2012 yılları arasında Bolette B. Blaagaard tarafından uluslararası gazetecilik bölümü öğrencileriyle gerçekleştirilmiştir. Bu çalışmada da odak gruplar aracılığıyla görüşlerine başvurulan farklı ülkelerden uluslararası gazetecilik bölümü öğrencileri yurttaşların haber üretimine katılımını gazetecilik üretimine bir saldırı olarak değerlendirmişlerdir (Blaagaard, 2017: 247).

Blaagaard'ın araştırmasında bu çalışmada da ortaya çıkan sonuçlara benzer biçimde “öğrenciler, yeni teknolojik gelişmelerin, herkesi potansiyel bir gazeteciye dönüştürmeye yeteceğini kabul ettikleri halde, kamu ile kendileri veya kendi meslekleri arasında açık bir ayrım olduğunu savunurlar" (Blaagaard, 2017: 247). 


\section{Sonuc}

Giresun Üniversitesi Tirebolu İletişim Fakültesi bünyesinde 2017-2018yılı bahar dönemi gerçekleştirilen Uygulama Atölyesi'nin özellikle öğrencilere sektöre dâhil olmadan önce donanımlarını geliştirebilecekleri bir olanak sağladığı anlaşılmaktadır. Bu bağlamda öğrencilerin sınırlı bir sürede hem gazete çıkarma pratiği hem de Günimedya ajansa yönelik katkıları dikkate değerdir. Bu öğrenciler arasından seçilmiş bir grup ile yapılan odak grup görüşmeleri doğrultusunda da mesleğe ve mesleki alanda ortaya çıkan dijital gelişmelere yönelik bakış açıları da değerlendirilmiştir. Sonuç olarak gazetecilik mesleğine yönelik olumlu ve olumsuz kavrayışların bir arada ifade ediliyor ve en çok vurgulanan özelliğinin de "zor bir meslek" olması öne çıkmaktadır. Tarihe tanıklık etmek olarak tanımlanan/ tariflenen deneyim de olumlu bir boyut olarak ifade ediliyor. Mesleği tanımlayan temel ilkeler sorulduğunda çoğunlukla gazetecinin bireysel olarak konumuna ilişkin nesnellik ve özgürlük olarak ifade edilen vurgular dikkat çekiyor. Dijitalleşme sürecine dair de öğrenciler büyük çoğunlukla olumsuz görüşler ifade ederken, özellikle sosyal medyaya ilişkin vurgu belirgindir.

Meslek bağlamında gazeteciliği bir meslek olmanın dışına çıkaran ve sıradan her bireyin gerçekleştirebileceği bir eyleme dönüştürdüğüne ilişkin bakış açısı önemlidir. Öğrencilerin alana ilişkin yeni tartışmalara (robot gazetecilik, kitle fonlu gazetecilik, veri gazeteciliği vb.) vakıf olmadıkları anlaşılmaktadır. Özellikle robot gazeteciliğe dönük kavrayışları popüler medyada yer alan robot temsilleri üzerinden şekillenmekte ve yapay zeka ve algoritma tartışmaları hiç anılmamaktadır. Özellikle yurttaş gazeteciliği tartışmaları bağlamında araştırmaya katılan öğrenciler mevcut medya yapısı içerisinde özellikle inbar hatları dolayımıyla gerçekleştirilen enformasyon aktarım sürecini eleştirel bir gözle değerlendirmekte ve bu türden pratiklerin haberin neliğine ilişkin ciddi tartışmalar geçirmesi gerektiğini ifade etmektedirler. Öğrencilerin bu vurguları James Curran'ın ifade ettiği (2017: 135) üzere gazeteciliğin geleceğini pasif bir şekilde tahmin etmek yerine aktif bir şekilde geleceğin şekillendirilmesine dâhil olmak noktasında önemli bir katkı olabilir.

\section{Kaynakça}

Aziz, A. (2003). Araştırma Yöntemleri Teknikleri ve Illetişim. Ankara: Turhan Kitabevi.

Blaagaard, Bolette B. (2017). Değişen Sınırlar: Nesnellik, Yurttaş Gazeteciliği ve Yarının Gazetecileri. Yeni Medya Geleceğin Gazeteciliği. (H. Hülür ve C. Yaşin, Ed.). Ankara: Ütopya Yayınevi. 238- 258.

Curran, James. (2017). Gazeteciliğin Geleceği. Yeni Medya Geleceğin Gazeteciliği. (H. Hülür ve C. Yaşin, Ed.). Ankara: Ütopya Yayınevi. 118-138.

Glesne, C. (2013). Nitel Araştırmaya Giriş. (A.Ersoy ve P.Yalçınoğlu, Çev. Ed.). Ankara: Anı Yayıncılık.

Karaduman, M. (2015). A Critical View on Communication Education and Training: an Evaluation in the Context of Communication High School. Procedia-Social and Behavioral Sciences. 174: 3033-3038. 
Kuş, E. (2007). Nicel-Nitel Araştırma Teknikleri. Ankara: Anı Yayıncılık.

Mayring, P. (2011). Nitel Sosyal Araştırmaya Giriş. (A. Gümüş ve M.S. Durgun, Çev.). Ankara: Bilge Su.

Pavlik, JohnV. (2013). Yeni Medya ve Gazetecilik. (M. Demir ve B. Kalsın, Çev.). Ankara: Phoenix Yayınevi. 